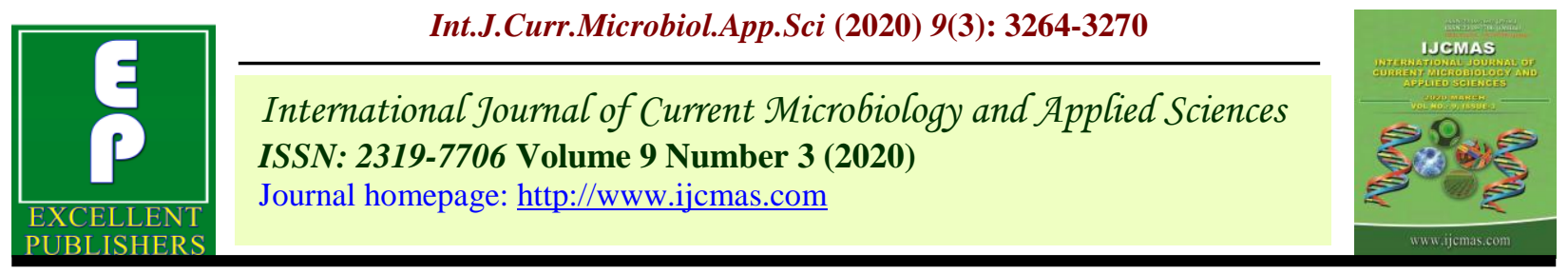

Original Research Article

https://doi.org/10.20546/ijcmas.2020.903.374

\title{
Preparation of Curve Number Map for hydrologic simulation using GIS and HEC-Geo-HMS Model
}

\author{
Karnika Dwivedi* and M.P. Tripathi
}

Department of Soil \& Water Engineering, SV College of Agricultural Engineering and Technology \& Research Station, Faculty of Agricultural Engineering, Indira Gandhi Krishi

Vishwavidyalaya Raipur - 492012, Chhattisgarh, India

*Corresponding author

K e y w o r d s
GIS,
Curve number(CN),
Hydrologic models,
HEC-Geo-HMS,
Land use,
watershed planning
Article Info
Accepted:
28 February 2020
Available Online:
10 March 2020

Keywords

GIS,

Hydrologic models,

HEC-Geo-HMS,

Land use,

watershed planning

Article Info

Accepted:

28 February 2020

10 March 2020

\section{A B S T R A C T}

The study is carried out with a purpose to apply various techniques and models for the delineation of catchment and developing methods in order to calculate the Curve Numbers for the Manendragarh watershed (1023.96 $\mathrm{Km}^{2}$ ) of upper Hasdeosubbasin, by implementing three software's i.e. Arc View GIS 10.4 with Arc Info, Arc Hydro Tool and Geospatial Hydrologic Modeling Extension (HEC-Geo HMS version 10.3) model for Arc View GIS 10.3. Multi layers like soil layer, DEM and Land Use Land Cover layer was combined and CN grid map was prepared. In particular, SCS-CN (Soil Conservation Curve Number) is a model through which the estimation of the direct runoff can be achieved. This method comprises numerous important properties of the watershed such as Hydrological Soil Groups and land use, which will use as an input for various hydrological model.

\section{Introduction}

Soil Conservation Services and Curve Number (SCS-CN) technique is one of the simplest methods for rainfall runoff modelling. A curve number $(\mathrm{CN})$, an index developed by the Soil Conservation Service (SCS) now called the Natural Resource Conservation Service (NRCS), is used to estimate the amount of rainfall that infiltrates into the soil and the amount of surface runoff Chin, 2000; Durrans, 2003.
The traditional method of delineating a watershed area from the topographic map is time consuming and is inaccurate. This traditional method has been replaced by the automatic extraction from a Digital Elevation Model (DEM). The DEM data have been used to derive geomorphic and topographic characteristics such as terrain slope, Elevation, aspect, contour line, hillshade andview shade. The data are collected which includes Soil map, Land Use Land Cover map, Slope map, Digital Elevation Model of 
the study area. These collected data were then used for preprocessing in ArcGIS 10.3, ArcHydro 10.3 and HEC-Geo-HMSin order to extract the Curve Number of the study area. These Curve Number plays an important role in any hydrological modelling such as the rainfall-runoff model for calculating runoff volume and peak discharges. HEC-GeoHMS is an extension of geospatial hydrological modeling developed by HEC for the expeditious construction of hydrological models rather than manual methods (HECGeoHMS 2003). It was designed for the ArcView 3.x platform, and requires an extension of the Space Analyst.

\section{Materials and Methods}

\section{Study area}

Manendragarh watershed of upper Hasdeo sub-basin was selected for current study. It lies between $82^{\circ} 04^{\prime}$ to $82^{0} 20^{\prime} 16^{\prime \prime}$ of East longitude and $23^{\circ} 03^{\prime} 0$ " to $23^{\circ} 18^{\prime} 19^{\prime \prime}$ of North latitude (Fig. 1) and covers an area of $1023.96 \mathrm{Km}^{2}$. On the security of various watershed of part of Mahanadi basin in Chhattisgarh Manendragarh of upper Hasdeo sub basin is selected in this study.

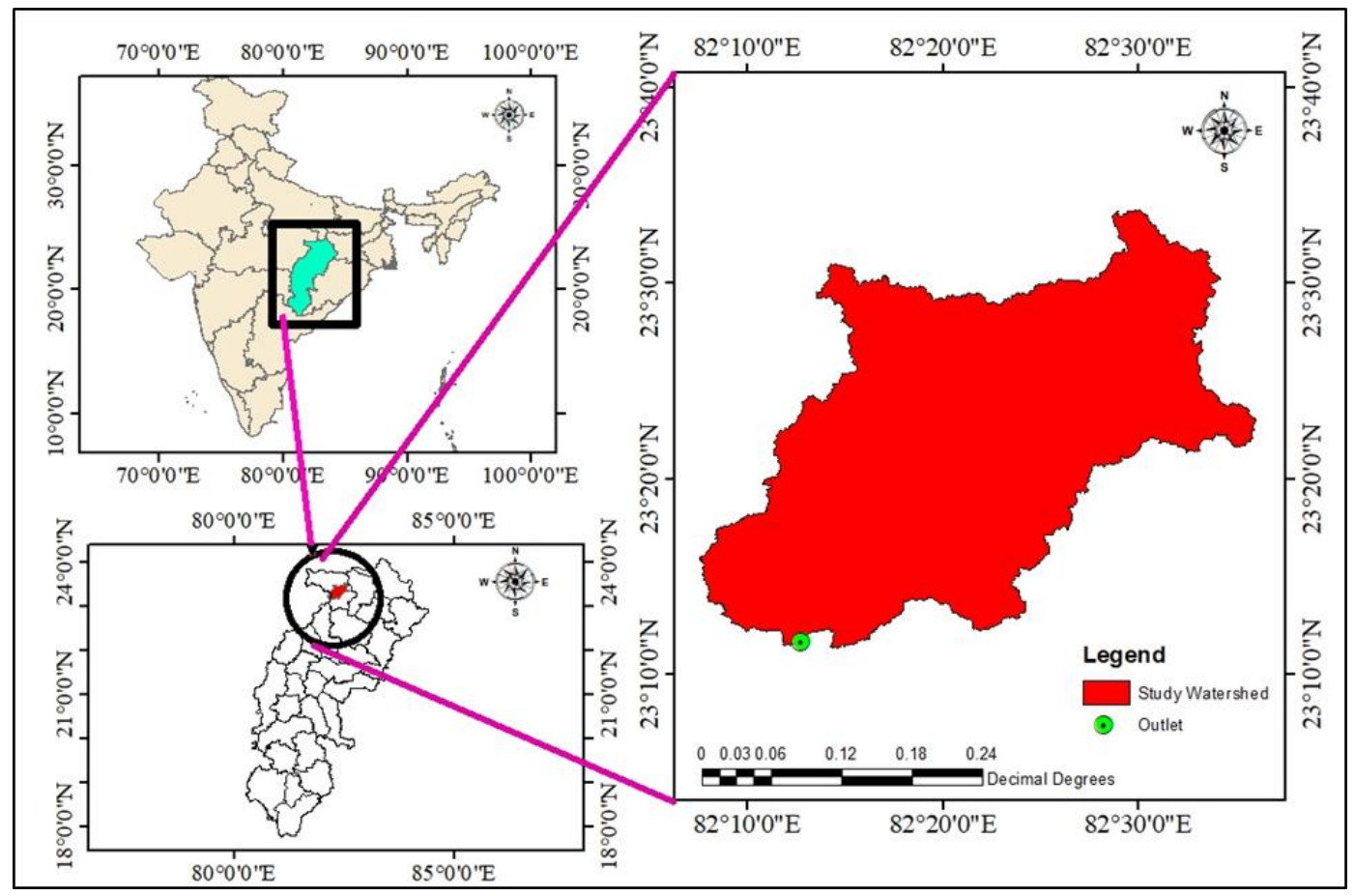

Fig. 1: Location of study area (Manendragarh watershed)

\section{Data Processing}

ArcGIS 10.3 and Arc Hydro Tools were used for pre-processing the collected data for the study area. The DEM used for current study was downloaded from website https://vertex.daac.asf.alaska.edu Alaska Satellite Facility (ASF) DAAC, 2015.The length-slope factor, slope, gradient, watersheds and sub- watershed of boundaries and drainage pattern are extracted from the DEM, therefore a highly reliable techniques and source adopted for formation of DEM. In order to perform geometric correction, the DEM was re-projected to Universal Transverse Mercator (UTM) co-ordinate system with Datum WGS 1984 (Zone-44) with spatial resolution of $12.5 \mathrm{~m}$. DEM of 
Manendragarh watershed is shown in Fig. 2. The land use and Hydrological Soil Group map (HSG) were generated to calculate the Curve Number and for the preparation of rainfall-runoff model by the mean of HECHMS.

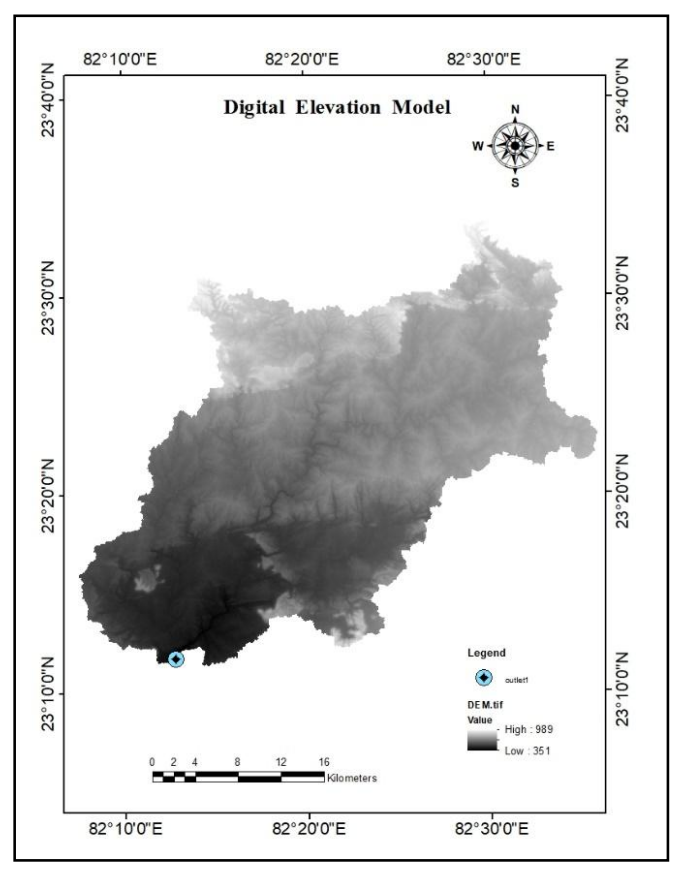

Fig.2 DEM of study area

\section{Results and Discussion}

\section{Delineation of the Manendragarh watershed from DEM}

The extraction of the drainage network of the study area was carried out from the DEM, in raster format $12.5 \times 12.5 \mathrm{~m}$ grid cell size. Archydro tools in ArcGIS software, version 10.3 was used to extract drainage channels through ArcHydro. The delineation of the watershed is followed by running the following functions (Fig. 3). Fill, flow accumulation, Flow direction, Stream definition, Stream Segmentation, Catchment Grid Delineation, Catchment Polygon, Drainage line, Adjoint Catchment processing and Drainage point.

\section{Land Use Map}

The numbers in land use shown in Fig. 4 represent the land use class defined according to the USGS land cover institute (LCI). However, LULC map were reclassified into four categories 1,2,3 and 4. The classification system used for NLCD is modified from the Anderson land-use and land-cover classification system. Many of Anderson classes especially the level III classes are best derived using aerial photography.

\section{Soil Map}

The soil texture map of the study area was prepared by using $10 \mathrm{Km}$ grid data accrued from NBSS and LUP, Nagpur. The shape files of the soil data were also collected from Chhattisgarh State Watershed Management Agency, Government of Chhattisgarh, Raipur. The soil map of the study water is shown in Fig. 5.

\section{Generation of Curve Number Grid Map}

The information needed to determine a curve number is the hydrologic soil group, which indicates the amount of infiltration that occurs in each type of soil. There are four hydrologic soil groups: A, B, C and D. The definition of each is given in Table 1.

Four fields named PctA, PctB, PctC, and PctD were created. For Manendragarh watershed, only one soil group assigned to each polygon so a polygon with soil group "A" will have PctA $=100, P \operatorname{ctB}=0, P \operatorname{ctC}=0$, and PctD $=0$. Similarly, for a polygon with soil group D, only PctD = 100, and the other three Pcts are zero.

The attribute table below was obtained. After the calculations were done, the Soil Code will be populated with letters A, B, C, D .By using the Union tool in Arc Tool box, Soil and Land Use map of study area were merged and $\mathrm{CN}$ Look-Up table was provided using Arc Catalogue as shown in Fig.6 and Fig.7. 
The SCS CN table gives $\mathrm{CN}$ for different combinations of land use and soil group, the Curve Number parameter is dimensionless and varies from 0 (maximum infiltration) to 100 (zero infiltration). The $\mathrm{CN}$ map has been obtained from the intersection of the soil hydrological group and landuse. The values of $\mathrm{CN}$ of the Manendragarh Watershed are lies between 100 and 30as shown the Fig. 8.
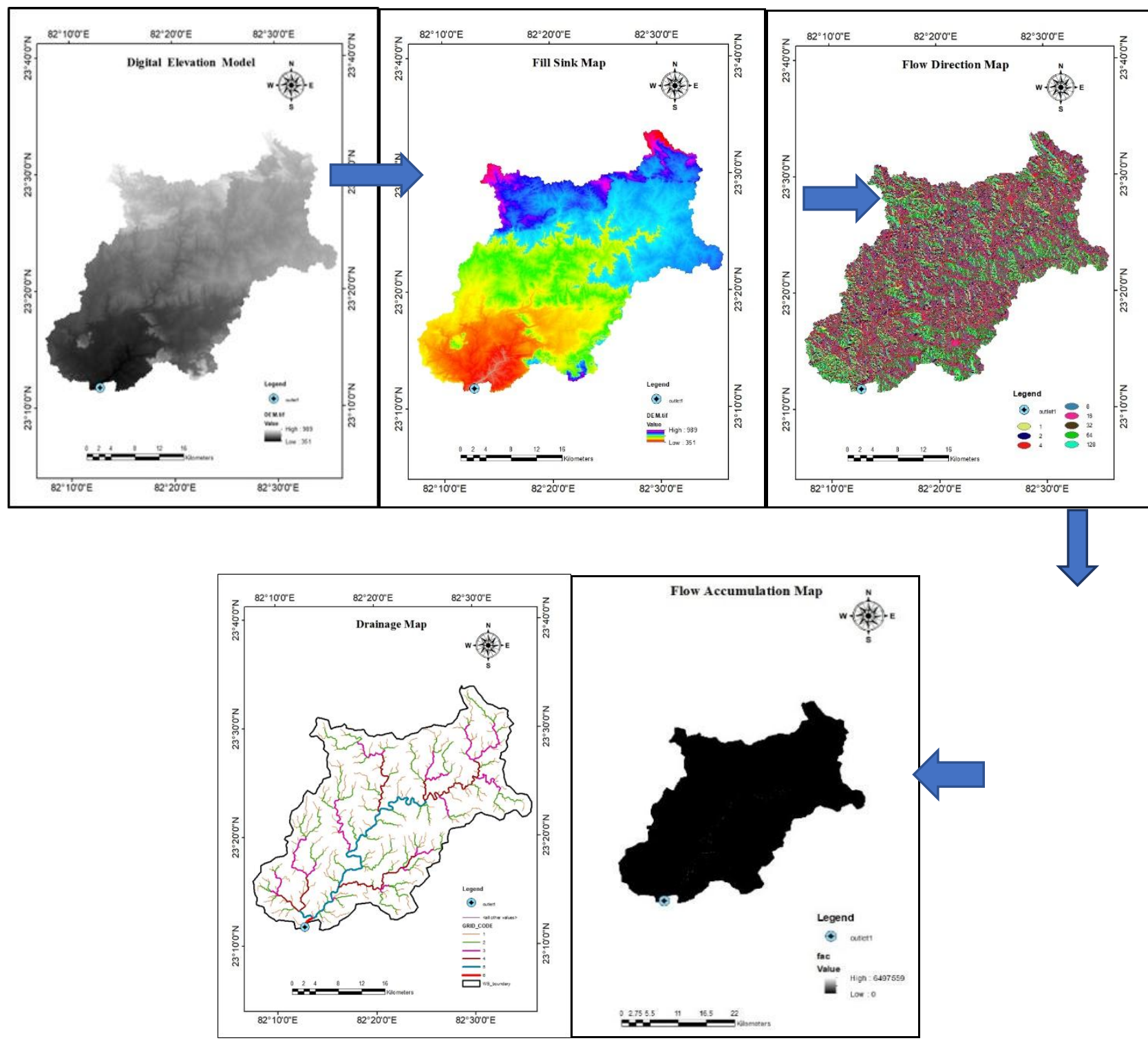

Fig.3 Results of ArcHydro Model 


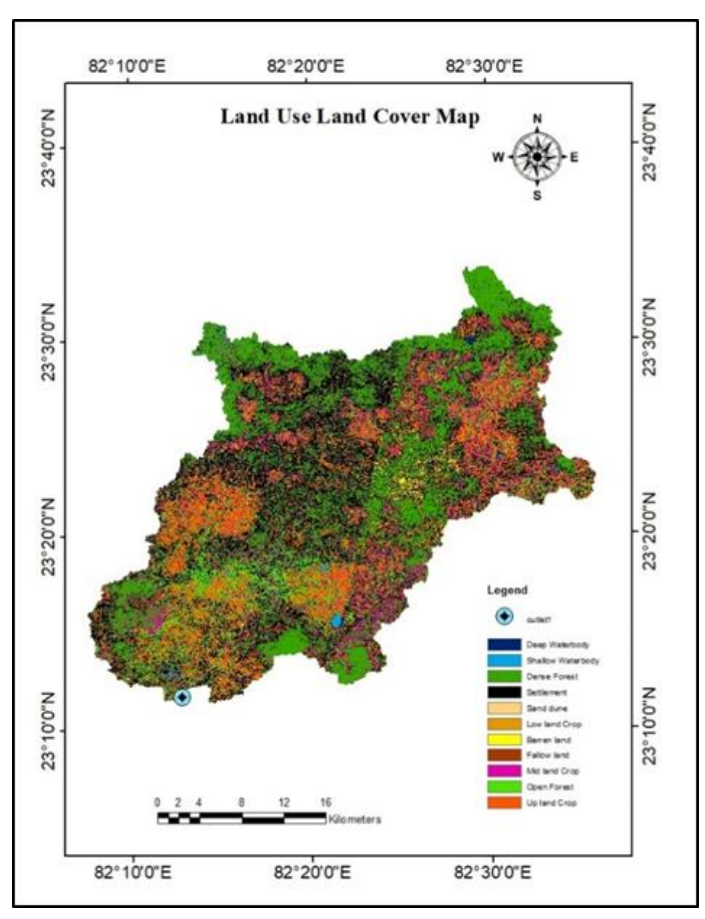

Fig.4 LULC map of study area

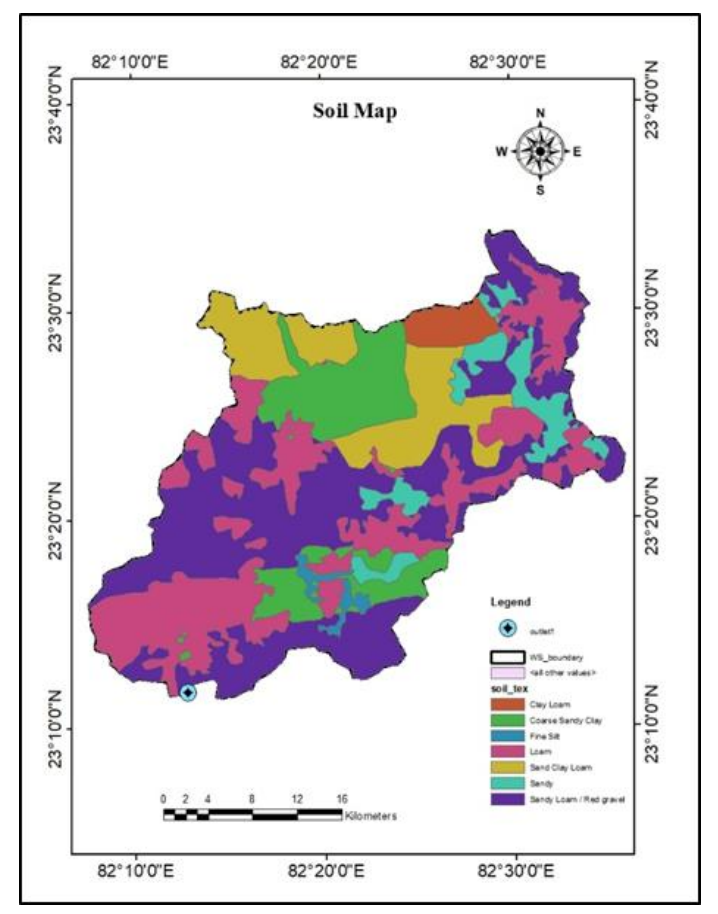

Fig.5 Soil map of study area

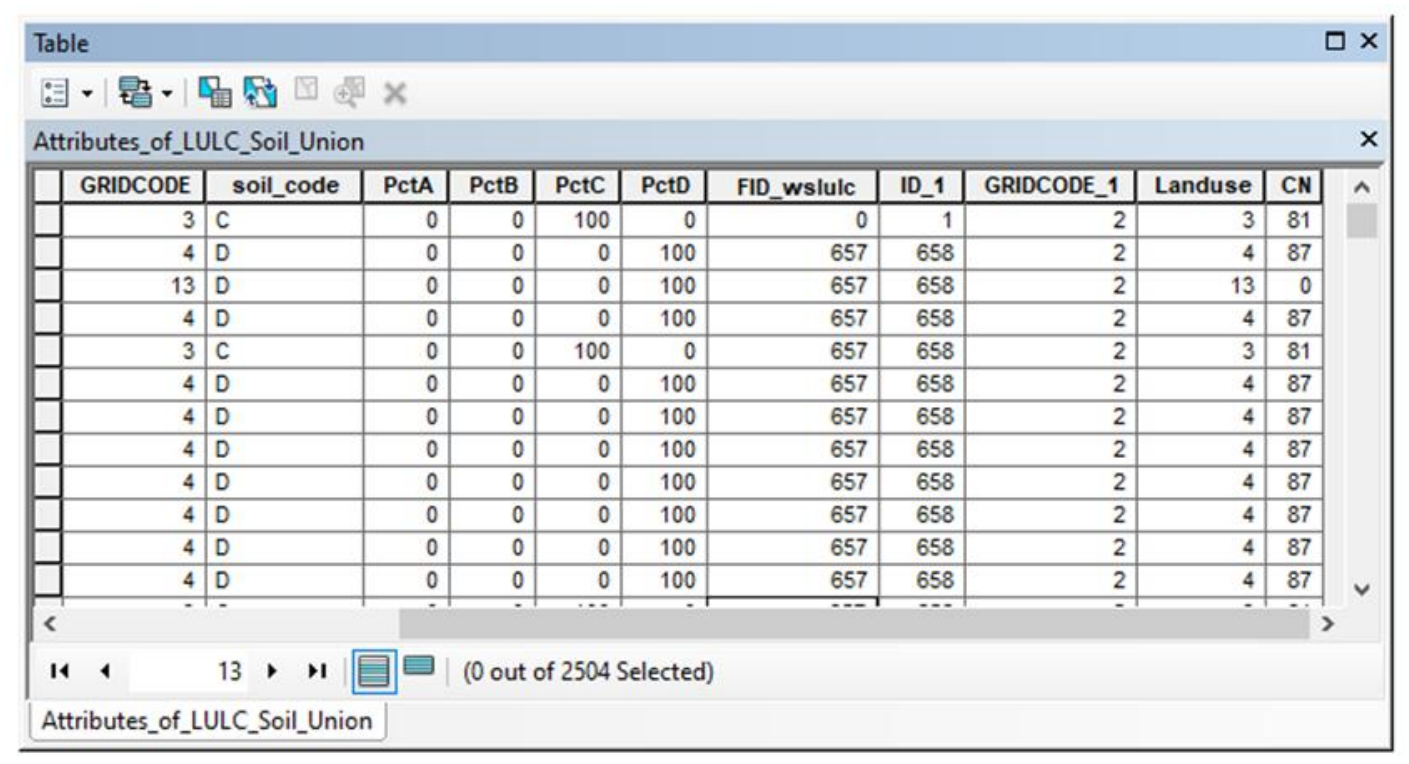

Fig.6 Attribute table of Soil and LULC union map 
Table.1 Description of NRSC soil groups, James et. al., 2010

\begin{tabular}{|c|l|c|}
\hline Group & \multicolumn{1}{|c|}{ Description } & Saturated hydraulic conductivity (in/hr) \\
\hline $\mathbf{A}$ & $\begin{array}{l}\text { High infiltration rates, well to } \\
\text { excessively drained sands or gravels }\end{array}$ & $\geq 0.45$ \\
\hline $\mathbf{B}$ & $\begin{array}{l}\text { Moderate infiltration rates, shallow } \\
\text { loses, sandy loam }\end{array}$ & $0.30-0.15$ \\
\hline $\mathbf{C}$ & $\begin{array}{l}\text { Slow infiltration rates, clay loams, } \\
\text { shallow sandy loam }\end{array}$ & $0.15-0.05$ \\
\hline $\mathbf{D}$ & $\begin{array}{l}\text { Very slow infiltration rates, } \\
\text { consisting chiefly of clay soil }\end{array}$ & $0.05-0.00$ \\
\hline
\end{tabular}

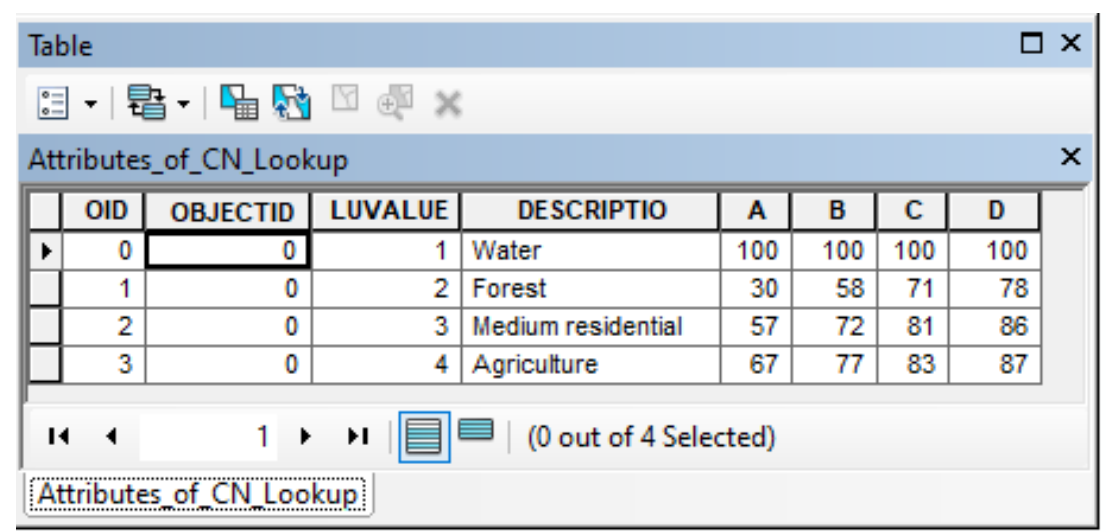

Fig.7 CN lookup table for Manendragarh watershed

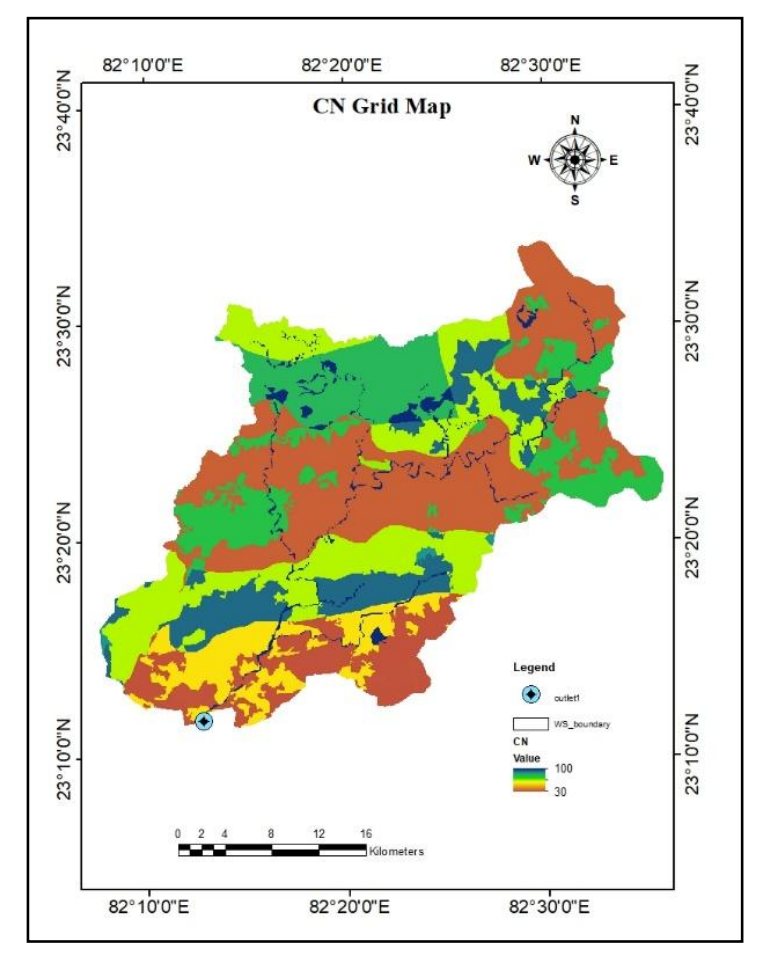

Fig.8 CN grid Map of study area 
In conclusion, As a result, ArcGIS, Archydro and HEC-Geo-HMS tools were used to determine the Curve Number Of study area which can be used as an input for various models by determining various hydrological arameters which have spatial characteristic and also for computing the peak Discharge and loss infiltration using theSCS-CN method.

The present study also demonstrates the importance of GIS techniques and remote sensing and their utility for delineation of Manendragarh watershed. This paper is also dealing with a reliable method for computing the $\mathrm{CN}$ values, which combines Land use and Hydrological soil group. The values of $\mathrm{CN}$ of the Manendragarh Watershed are lies between 100 and 30. The results showed that a $\mathrm{CN}$ of 100 means surface water. The high curve numbers (100-81) corresponding to urbanized areas indicate high runoff and low infiltration; while low curve numbers (77-30) corresponding to the forested area means low runoff and high infiltration rate.

\section{References}

Chin, D. A., 2000. Water Resources Engineering. Upper Saddle River, New Jersey: Pearson Prentice Hall.

\section{How to cite this article:}

Karnika Dwivedi and Tripathi, M.P. 2020. Preparation of Curve Number Map for hydrologic simulation using GIS and HEC-Geo-HMS Model. Int.J.Curr.Microbiol.App.Sci. 9(03): 32643270. doi: https://doi.org/10.20546/ijcmas.2020.903.374
Durrans, H., 2003, Stormwater Conveyance Modeling and Design. Haestad Press, Waterbury, CT. Environmental protection agency 841-B-09-001. Washington, DC.

HEC-GeoHMS 2003. Geospatial Hydrologic Modeling Extension HEC-Geo HMS v. 1.1-User's Manual. U.S. Army Corps of Engineers-Hydrologic Engineering Center (HEC), CPD-77, Davis, CA.

James, W. R. C., Rossman, L. E., \& James, W. 2010, User's Guide to SWMM5: Computational Hydraulic International (CHI), 12th edition. USA.

United States Geological Survey (USGS), 2013, Land Cover Institute (LCI) NLCD land Cover Class Definitions. Retrieved from http://landcover.usgs.gov>.

Khaddorliasse and Alaoui Adil Hafidi, 2014, Production of a Curve Number map for Hydrological simulation - Case study: Kalaya Watershed located in Northern Morocco. International Journal of Innovation and Applied Studies, Vol. 9 No. 4 Dec. 2014, pp. 1691-1699. 